\title{
Pengaruh warna umpan buatan terhadap hasil tangkapan pancing noru di perairan Teluk Manado
}

\author{
The effect of artificial bait color on the catch of trevally handline in Manado Bay \\ ISROJATY J. PARANSA*, WILYAM R. TIPINBU dan HENRY J. KUMAJAS \\ Program Studi Pemanfaatan Sumberdaya Perikanan, Fakultas Perikanan dan Ilmu Kelautan, \\ Universitas Sam Ratulangi, Manado 95115
}

\begin{abstract}
One of the fishing gears used by fishermen in the Bay of Manado to catch pelagic fish is handlines with various types and sizes, whether using natural baits or artificial baits. One type of handlines using artificial lures is noru. It is operated using artificial baits made of colored fabric yarn. To provide scientific information about the most preferable artificial bait color, a research on artificial bait color difference to total catch of small pelagic fish in Manado Bay. The results show that red and blue artificial lures were the most productive to catch small pelagic fish of trevally (Selaroides sp) and scad (Decapterus sp). While the best fishing time was from 18:00 to 20:59.
\end{abstract}

Keywords: artificial bait, color, pancing noru, Manado Bay

\begin{abstract}
ABSTRAK
Salah satu alat tangkap yang digunakan oleh nelayan Teluk Manado dalam upaya penangkapan ikan pelagis adalah pancing ulur dengan berbagai jenis dan ukuran, baik yang menggunakan umpan alami ataupun umpan buatan. Salah satu jenis pancing ulur yang menggunakan umpan buatan adalah pancing noru. Pancing noru dioperasikan menggunakan umpan buatan dari serat kain berwarna-warni. Untuk mendapatkan informasi ilmiah tentang warna umpan buatan yang paling disukai ikan pelagis kecil, telah dilakukan penelitian tentang perbedaan warna umpan buatan terhadap jumlah hasil tangkapan ikan pelagis kecil di perairan Teluk Manado. Hasil yang didapat menunjukkan bahwa umpan buatan warna merah dan biru yang paling banyak memberikan hasil tangkapan ikan pelagis kecil yakni ikan selar (Selaroides sp) dan ikan malalugis (Decapterus sp). Sedangkan waktu operasi yang terbaik adalah pada jam 18.00 sampai dengan 20.59 .
\end{abstract}

Kata-kata kunci: umpan buatan, warna, pancing noru, Teluk Manado

\section{PENDAHULUAN}

Pada awal tahun 1980, wilayah pesisir pantai Teluk Manado mengalami perubahan yang sangat cepat akibat adanya kebijakan pemerintah untuk melakukan pembangunan jalan Boulevard di sepanjang pesisir pantai Teluk Manado mulai dari Kelurahan Bahu sampai Kelurahan Texas. Keadaan ini semakin sulit bagi nelayan sejak terjadinya proses pembangunan reklamasi pantai Teluk Manado yang berakibat hilangnya beberapa fishing ground sepanjang pesisir pantai. Keadaan inilah yang memaksa nelayan untuk melakukan upaya-upaya penangkapan ikan di luar wilayah penimbunan (Anonimous, 2011).

\footnotetext{
*Penulis untuk penyuratan; email: iparansa@yahoo.com
}

Alat tangkap yang digunakan oleh nelayan Teluk Manado dalam upaya penangkapan ikan adalah pancing ulur dengan berbagai jenis dan ukuran, baik yang menggunakan umpan alami ataupun umpan buatan. Salah satu jenis pancing ulur yang digunakan adalah pancing noru. Pancing noru dioperasikan menggunakan umpan buatan dari serat kain berwarna-warni. Serat kain tersebut ada yang diikatkan langsung pada mata pancing, dan ada juga yang direkatkan dan diikat pada kulit pembungkus kabel kecil. Warna umpan buatan yang dikenal umum oleh nelayan Teluk Manado adalah merah, biru, kuning, hijau dan putih. Warna umpan buatan yang paling dominan menangkap ikan dengan alat pancing noru belum dapat mereka 